\title{
CONTEMPORARY RELATIONS OF SERBIA AND CHINA IN A CHANGING WORLD ${ }^{2}$
}

https://doi.org/10.18485/iipe_balkans_rssc.2020.ch16

\begin{abstract}
The contemporary relations of the Republic of Serbia with the People's Republic of China (hereinafter: Serbia and China) are conditioned by many political, legal, economic and social factors. Although these factors determine the mutual relations between the two countries, in the end, these factors do not limit the great opportunities for developing good and friendly relations imbued with mutual respect and trust. Even more so, in the historical and international legal sense, the relations of the two countries are characterized by the continuity of diplomatic relations established on 2 January 1955 between the then Federal People's Republic Yugoslavia and the People's Republic of China. Serbia as the successor state of SFR Yugoslavia continues to treat China as one of its most important partners in international relations, which is manifested through the foreign policy course, according to which China is one of the main 'pillars' of Serbia's foreign policy alongside the European Union, Russia and the United States. Hence, the mere mention of 'pillars' in Serbia's foreign policy orientation indicates that China is a key player in international politics for Serbia and a great power with which it should build its relations and deepen its friendship in accordance with the already established policy framework on the Comprehensive Strategic Partnership. This approach should come as no surprise since the development of Serbian-Chinese relations at the bilateral and multilateral levels (especially at the $\mathrm{UN}$, regional international organizations and political forums, such as the ' $17+1$ ' cooperation mechanism between China and Central and Eastern European countries) contributes to a better strategic positioning of Serbia and China in the world of global change.
\end{abstract}

Keywords: Serbia, China, contemporary international relations, foreign policy determinants, strategic partnership.

\footnotetext{
${ }^{1}$ Principal Research Fellow, Institute of International Politics and Economics, Belgrade, Serbia. E-mail: dimitrijevicd@diplomacy.bg.ac.rs.

${ }^{2}$ The paper presents findings of a study developed as a part of the research project "Serbia and challenges in international relations in 2020", financed by the Ministry of Education, Science, and Technological Development of the Republic of Serbia, and conducted by Institute of International Politics and Economics, Belgrade.
} 


\section{INTRODUCTION}

Today's world is marked by globalization as a comprehensive and multilayered process of transformation of the international community. This transformation is taking place in parallel with efforts to democratize international relations, which presupposes increased social interdependence in economic, political, legal, scientific and technological, cultural, religious and humanitarian fields (Dimitrijević and Vučić, 2016, p. 9). In international relations, increased interdependence has led to a change in the international community based on traditional assumptions about state sovereignty. This is certainly the most obvious in the economic sphere where, regardless of the political system to which states incline, states strive to gain equal access to world markets in order to achieve their economic development. This development is not possible without the internationalization of the world economy and the division and transfer of functional competences between state and non-state actors. ${ }^{3}$ The justification for these processes lies in the neoliberal concept of social integration, which explains the increasing dependency between different actors in international relations (Haas, 1964; Riphagen, 1977, p. 122). Based on these doctrinal assumptions, globalization is imposed as a necessary process of social development that removes the differences between the goals of domestic and foreign policy, and which then reconciles the conflict that exists between domestic and international competences in different spheres of social activities, including economic activities. Hence, in new world's political circumstances, through the process of globalization, countries improve trade, technology and communications, remove tariffs and trade barriers, improve transparency and permeability of national borders, all with the aim to accelerate economic activities and improve living conditions not only for their own well-being but for the benefit of all mankind. In this sense, this process can help remove restrictions on the movement of goods, services, people, and ideas. Consequently, while globalization in the economic sphere involves the liberalization of crossborder trade cooperation, capital markets, investment and production, the importance of globalization is much broader because it integrates human behaviour and connects social activities through the dynamics of intensified political, economic, legal and other integration at regional, continental and planetary level (Pečujlić, 2005, p. 17). In this context, the international system

\footnotetext{
${ }^{3}$ The functional division of competences encompasses the integration of the theory of international relations and its functionalist approach.
} 
of governance is transformed into a New World Order, which through the multiplication of actors in international relations and the humanization of international law, seeks to satisfy the common interests of the entire international community. This process, in itself, requires further liberalization, integration and legitimization of state policies in the wider international space (Allot, 1998, p. 409; Koskenniemi, 1989, p. 21).

The process of globalization has not bypassed Serbia and China. In the past decades, both countries have sought to improve the structure of their economies and increase the quality of economic growth through strenuous social, political, economic, and legal reforms. Both countries were involved in the process of globalization through a series of political decisions and reform measures that contributed to the radical changes in the economic system and the transformation of the then existing pattern of economic development. On the one hand, China could not take on a leading role in the global economy without opening up and entering the world markets, intensifying its industrial and trade business, stimulating scientific and technological development and enhancing the international economic cooperation that brought accelerated economic growth and an increase in the overall standard of living. On the other hand, without reconstruction and restructuring of destroyed industrial capacities, without rehabilitation of the banking sector and stimulation of investment business, Serbia would not be able to re-industrialize and thus win a more favourable position in international economic relations. The aforementioned progress in both countries was accompanied by appropriate and well-planned development policies and comprehensive foreign policy activities, which gradually led to their strategic repositioning in contemporary international relations. Consequently, this repositioning was greatly aided by the establishment of numerous interstate links and connectivity with other international actors (especially international governmental and non-governmental organizations, transnational corporations, forums for international cooperation, etc.), which facilitated the deepening and transformation of bilateral and multilateral cooperation into strategic partnerships. In this respect, the Comprehensive Strategic Partnership between Serbia and China established in 2016 represents a higher level of a strategic partnership initiated and validated in 2009 and 2013 (Ministry of Foreign Affairs of the PRC, 2009, 2013, 2016). The Comprehensive Strategic Partnership is based on traditionally good and friendly relations between the two countries, on mutual respect, equality, non-interference, mutual understanding and support for an independent path of development that includes independence in internal and foreign policy in accordance with their own circumstances (Obradović, 2016, p. 128; 
Tanjug, 2016). ${ }^{4}$ As globalization poses unprecedented challenges to the contemporary world, Serbia and China have responded to these challenges with a solid form of connectivity to create an environment necessary for the optimal development of their economies and the achievement of their foreign policy goals and priorities.

The study that follows is based precisely on this thesis on the development of the Comprehensive Strategic Partnership of Serbia and China in the Age of Globalization. Specifically, the study analyses the general, specific and unique foreign policy determinants through which the author wishes to confirm the validity of the initial hypothesis that the current strategic cooperation between Serbia and China depends not only on spatial, temporal and institutional factors, which are evidently asymmetrical, but also from the global economic factors that can, in perspective, contribute to deepening this cooperation.

\section{GENERAL FOREIGN POLICY DETERMINANTS OF SERBIA-CHINA RELATIONS}

The factors that determine Serbia's current foreign policy stem from the country's past and present development. The historical development of Serbia before and within Yugoslavia, and then the development of Serbian statehood after the Yugoslav breakup, had a great influence on Serbia's contemporary relations with other states. The significance of this development is great because despite its great historical difficulties and temptations, Serbia has managed to preserve the nucleus of its territory and population, and to a large extent the international relations of the former Yugoslavia, whose positive and negative effects determine its foreign policy position in the modern world. Therefore, Serbia's current relations with China deserve serious attention because they are conditioned by the political determinants of the Yugoslav-Chinese past, as well as the socio-economic variables that have arisen from the internal development of the two countries. An analysis of these factors provides a good basis for considering the effects of foreign policies so far. However, before determining their concrete significance, it is necessary to analyze the geopolitical and economic

\footnotetext{
${ }^{4}$ The strategic partnership was established in August 2009, during the visit of then Serbian President Boris Tadić to China. In August 2013, the Serbia-China Partnership was confirmed to be extended to the Comprehensive Strategic Partnership in June 2016 through a joint statement by former Serbian President Tomislav Nikolić and Chinese President Xi Jinping.
} 
factors that determine the position of Serbia and China in contemporary international relations. In this regard, the following analysis begins with an analysis of the general facts about China in order to proceed with an analysis of the essential parameters relating to Serbia, which together condition their foreign policy position.

China is located partly in Central and partly in East Asia. Its land territory covers 9,326,410 square kilometres, making it the second-largest country on the Asian continent and the third-largest country in the world, just behind Russia and Canada. In addition, China is the most populous country in the world. It has over 1.433 billion inhabitants, or $1 / 5$ of the world's total population and 1/3 of Asia's total population (Šehić et al., 2007, p. 78; United Nations Department of Economic and Social Affairs, 2019, p. 17). There are 56 different ethnic groups in China, of which Han is the most numerous (about 91.5\%). Due to the different topography, climate and economic conditions of life, population density varies from developed eastern regions to less-developed western China. Despite striking demographic and economic disparities between regions, China has been able to achieve significant economic growth and social development after implementing planned reforms and opening up to the world, so that with its economic potential, China has ranked second in the world with a progressive GDP growth rate (International Monetary Fund, 2019). ${ }^{5}$ This unprecedented progressive trend in recent social history has led China to become the largest trading power in the world, with the largest export potential. China's economic driving force has contributed to expanding its militaristic capabilities (including nuclear capabilities), increasing its international position in the world for a relatively short period. China today plays an irreplaceable role in regional relations, and its economic and military potential in the near future secures it the place of a 'potential great power' (Global Fire Power, 2019; Perlo-Freemen, 2014). ${ }^{6}$ According to the socio-political order, China represents a secular state and republic according to the form of government. Despite numerous reforms and political and social transformations, China maintained a specific form of society with

\footnotetext{
${ }^{5}$ China's nominal GDP in 2019 is projected to reach 14.216 trillion US dollars, which is 10,153 US dollars per capita, while GDP based on purchasing power parity (PPP) stood at 27.331 trillion US dollars which is 19,520 US dollars per capita.

${ }^{6}$ By total military potential, China ranks third out of 137 countries in the world for which official data are available. China has the largest composition of the regular army. According to budget allocations, China is second in the world.
} 
more socialist than communist characteristics. Hence its economic system and market modes of business incline more to the capitalist than to the communist economic system, which China emphasizes on a daily basis as its advantage and peculiarity through the phrase 'socialism with Chinese characteristics' (Darlington, 2018). Therefore, the 1982 Chinese Constitution (amended in 1988, 1993, 1999 and 2004) precisely emphasizes the People's Republic of China represents a 'socialist state under a working-class democratic people's power based on an alliance of workers and peasants' (Darlington, 2018). Internally, China's political system is based on democratic centralism, embracing the principles of equality and unity and mutual assistance between different national communities (The State Council of the PRC, 2014). These principles are being implemented throughout China, which is administratively divided into 22 provinces, 5 autonomous regions (with minority peoples), 4 government-administered municipalities (called mainland China), as well as 2 separate administrative areas. ${ }^{7}$

In analyzing the key foreign policy determinants that condition Serbia's position in international relations, including the development of its relations with China, the following facts should be taken into account. Today's Serbia is a small continental country that covers an area of 88,361 square kilometres. Its geographical position in Southeast Europe and partly in Central Europe (in the Pannonia Plain) determines its strategic importance in the Balkan Peninsula. ${ }^{8}$ This is further evidenced by the fact that Serbia is connected to the pan-European transport corridors (with the corridor VII or the Danube corridor, and then also with the land transport corridor X connecting Serbia

\footnotetext{
${ }^{7}$ The Chinese provinces include Anhui, Fujian, Gansu, Guangdong, Gansu, Guizhou, Hainan, Hebei, Heilongjiang, Henan, Hubei, Hunan, Jiangsu, Jiangxi, Jilin, Liaoning, Qinghai, Shaanxi, Shandong, Shanxi, Sichuan, Yunnan, and Zhejiang. The Autonomous Regions of China include Guangxi-Zhuang, Nei Mengu - Inner Mongolia, Ningxia-Hui, Xinjiang-Uygur, Xizang Tibet. The municipalities under the direct administration of the Chinese Government are Beijing, Shanghai, Chongqing, and Tianjin. Hong Kong and Macau are within the regime of special administrative regions. China regards Taiwan as its 23rd province over which it has no effective control, but which, under the Constitution, is 'part of the sacred territory of the People's Republic of China'.

${ }^{8}$ Although Serbia is a land lock country, it is connected to Central Europe by large river routes and basins. Namely, the valleys of the Morava River in the north-south direction, as well as the Sava and Danube in the north-west-southeast direction, represent a morphological connection between the Balkans and the Central European Plains. Through its northern province of Vojvodina, which lies around the Danube River Basin, Serbia is connected by a large network of river routes to the Black, North and Baltic Seas, and through the Rhine-Main to the Atlantic Ocean.
} 
with Hungary in the north, Croatia, Slovenia and Austria in the west, Bulgaria and Turkey in the east and Macedonia and Greece in the south). Serbia is at the crossroads of strategically important east-west, north-south and south-east European routes. Therefore, although it has limited human capacities (about 8.7 million people live in Serbia, including the territory of Kosovo and Metohija), and very limited economic potential (which directly determine its military potential), its geostrategic position enables it to integrate more and participate in all major regional and international geoeconomic projects (UN Department of Economic and Social Affairs, 2019, p. 21; International Monetary Fund, 2019; Global Fire Power, 2019; Law on the budget of the Republic of Serbia, 2019). ${ }^{9}$ Nevertheless, its strategically important position enables Serbia to be the 'gateway to the Balkans', i.e., the 'bridge between East and West', which Serbia certainly is, taking into account all those variables and fluctuations in international relations that existed in the past, but still exist and are clearly an excellent prerequisite for optimal international positioning and sustainable socio-political, economic and cultural development.

In terms of political order, Serbia is a republic dominated by parliamentary democracy. By economic order, Serbia is a capitalist state. According to the current Constitution of 2006, 'The Republic of Serbia is a state of the Serbian people and all its citizens, based on the rule of law and social justice, the principles of civil democracy, human and minority rights and freedoms and membership of European principles and values' (Constitution of the Republic of Serbia, 2006). The territory of Serbia is unique and indivisible, and the borders are inviolable. The state power in the territory is limited by the Constitution in such a way that the Constitution guarantees the rights of citizens to provincial autonomy and local self-government. In that sense, Serbia formally has two autonomous provinces: Vojvodina and Kosovo and Metohija. Following the escalation of armed conflicts and NATO intervention in 1999, the territory of the Autonomous Province of Kosovo and Metohija was placed under the United Nations administration, and soon thereafter internationalized. Due to inconsistent implementation of the established goals of internationalization,

\footnotetext{
${ }^{9}$ According to IMF data, Serbia's nominal GDP in 2019 is projected to reach 51.523 billion US dollars, which is 7,397 US dollars per capita, while GDP based on purchasing power parity (PPP) stood at 129.298 billion US dollars, which is 18,564 US dollars per capita. By total military potential, Serbia ranks on 79 places of 137 countries in the world for which official data are available. According to the Budget of the Republic of Serbia for 2019, for military needs is allocated 907 million US dollars, which is 1.75\% of Serbian GDP.
} 
i.e., the United Nations Interim Administration Mission in Kosovo has worsened the political and inter-ethnic situation over time, which led to the unilateral declaration of independence of the southern Serbian province by Kosovo Albanians on 17 February 2008. Serbia treats this separatist act as contrary to its legal order and international law and does not accept any violation of its territorial integrity or change of internationally recognized borders. In order to reach an acceptable and lasting solution for the status of Kosovo and Metohija after internationalization, and with the aim of exercising basic human rights, including freedom of movement, Serbia, with the intervention of the international community, has accepted the establishment of border crossings on its administrative line with the southern province (Dimitrijević, 2007; Dimitrijević et al., 2012).

Although, according to the analysis of general foreign policy, Serbia is a 'small state', it is an important political factor in the Balkans, given its geostrategic position. Such a syllogism stems from the premise that Serbia is located at the crossroads of Southeast Europe, on important land and river routes that enable it to communicate well not only in the east-west direction but also in the north-south direction. Also, such a syllogism stems from the fact that Serbia represents a 'piedmont' between Central Europe and the Middle East. Its geographical position, natural and human resources, sociopolitical system and orientation in international relations enable it to accelerate its economic development and integration into real economic trends whose personification is the European Union, with which China also strives to establish stable, long-term and inclusive relationships and whose market it is particularly interested in. Given these facts, it is clear that China has an interest in deepening and expanding strategic cooperation with Serbia.

In the context of the analysis of the current relations between Serbia and China, the aforementioned conclusion is logically imposed, primarily because of the historical experience that Serbia has, which indicates a lesser or greater degree of influence of the great powers on its foreign policy orientation (Gleni, 2001, p. 362). Namely, it cannot be disputed that in the previous historical period, Serbia has been building its independent foreign relations in search of allies, which were often great powers. The same need exists today when Serbia seeks to achieve its own foreign policy priorities, strategically important economic and social goals. This, of course, does not mean that Serbia should accept one's domination, but that it should cooperate with great powers through constructive and functional forms of cooperation based on equality, mutual understanding and benefits. Such a conclusion holds for Serbia's relations with China. As China formally 
supports Serbia's independence and is focused on developing friendly cooperation based on respect for the principles of the United Nations Charter and international law, it is clear that Serbia-China relations are based on equality, mutual benefit and trust.

Starting from the fact that the dynamics of geopolitical changes in the world require a new positioning of Serbia in international relations, deepening cooperation with China represents its foreign policy priority. The new foreign policy course includes a rethinking of the international environment and the ability to pursue vital national interests.

In the continuation of the study, the author paid attention to specific foreign policy determinants, which in his opinion may influence the further direction of the development of mutual relations.

\section{Specific foreign policy determinants of Serbia-China relations}

The fact that the diplomatic relations between the Federal People's Republic of Yugoslavia and the People's Republic of China were established on 2 January 1955 greatly contributed to China's strategic positioning towards Serbia. Even more so, since China considers Serbia a successor to Yugoslavian non-aligned foreign policy and a country that remained neutral in the military-political regrouping after the end of the Cold War. In addition, China's foreign policy orientation towards Serbia is also conditioned by the new political course that the Serbian government has set after the democratic changes since the beginning of the 21st century. Namely, after these changes, parliamentary democracy was introduced in Serbia, which is an important factor in the democratization of the country and its opening to the world. The new Serbian government has made further efforts since 2000, with the aim of establishing strategic relations with China, while simultaneously expanding and strengthening cooperation with the European Union, the United States of America and Russia (Isac Fund, 2013). In doing so, Serbia has identified these partners as the main pillars of its foreign policy, while affirming that China represents as important a political actor to it in international relations as other great powers. This foreign policy orientation is imbued not only with a voluntaristic assessment of overall international relations, but also with an opportunistic appreciation of China, which is increasingly acting not only for its own benefit, but also in the common interest as a responsible power and global player in solving major international problems. In a 
globalized world, China considers not only the personal interests and needs of the current generation of the world's population, but also the interests of other countries and the needs of future generations. Thus, for Serbia, cooperation with China is a key factor in achieving its most important foreign policy goals. In this regard, Serbia supports China, which in international relations does not strive for hegemony and imperialism, but advocates multilateralism in which the United Nations should play a primary role.

China's relationship with the world is characterized by the application of the Five Principles of Peaceful Coexistence, which involves the principles of mutual respect, territorial integrity and sovereignty, non-aggression, noninterference in internal affairs, equality and mutual benefit, as well as peaceful coexistence. ${ }^{10}$ These five principles of peaceful coexistence represented a political base for establishing friendly relations with countries that did not accept China's ideological commitment to communist rule. (United Nations, 1958, pp. 57-81; Ministry of Foreign Affairs of the PRC, 2019; Keith, 2009; Baijlie, 2014). Thanks to these principles, deeply embedded in the Chinese Constitution and the United Nations Charter, China has been able to establish and develop diplomatic relations with over 170 countries (including Serbia). This fact is not negligible given China's real ability to achieve a key foreign political goal - building a peaceful, stable and prosperous international order framed by the principle of 'harmony without uniformity', which seeks to overcome differences in social systems and ideologies in order to promote equality in international relations. That is certainly one of the preconditions for achieving the international development goals, more precisely formulated in the United Nations Millennium Declaration and Agenda for Sustainable Development. (Qingmin, 2014; Dimitrijević, 2018, p. 68; Ministry of Foreign Affairs of the PRC, 2015; United Nations, 2000; 2015). Achieving this foreign policy goal will entail enormous temptations and obstacles, such as rivalries with other great powers (most notably the United States of America), then multiple

\footnotetext{
${ }^{10}$ The concept was first proclaimed by former Chinese Prime Minister and Foreign Minister Zhou Enlai when he met with an Indian delegation in the early 1950s to regulate Tibet issue. This concept is also colloquially called the precepts of Pancha Sila, and is incorporated into the China-India Agreement on Tibet, concluded on 29 April 1954 in Beijing. More recently, the principles have also been upheld in numerous official announcements and bilateral treaties (for example, in a final statement from the Asian and African Conference in Bandung in 1955; in the 1972 Shanghai Joint China-US Communication; in the ChinaJapan Peace Agreement of 1978, etc.).
} 
internal tensions (regarding Tibet and Taiwan, and more recently Xinjiang and Hong Kong), and then the regional crisis (for example, in North Korea, Afghanistan, Syria, Iran, etc.). Of course, neither the territorial disputes with neighbouring countries (sovereignty on islands in the South and East China Sea), nor defining the land border with Bhutan and India, nor modern asymmetric security challenges (such as poverty, pandemics, natural disasters, environmental pollution, terrorism, international crime, etc.) cannot prevent China from trying to seek solutions peacefully and with high standards of strategic management (Almond, 2018; Bhutia, 2015; Heath et al., 2016, pp. 3-16; White House, 2017; Putten and Shulong, 2011, p. 218; Swaine, 2019; Yang, 2010, pp. 141-159).

For Serbia, as well as for China, the preservation of independence, national sovereignty and territorial integrity, and thus international peace and security, are the foreign policy priorities. In line with these priorities, both countries are developing defensive military doctrine and a neutral attitude toward military-political blocs (Hongjun, 2013, p. 9; Buzan, 2004, p. 70; Mitrović, 2008, p. 26; Resolution of the National Assembly of Serbia, 2007). Given this foreign policy and military orientation, it is clear why Serbia respects the One China Policy, which promotes the territorial integrity and sovereignty of the whole of China, including Taiwan. It is also clear why China, as a permanent member of the United Nations Security Council, insists on protecting Serbia's territorial integrity and does not accept the unilaterally declared independence of Kosovo and Metohija. It is well known that China is committed to upholding the consistent implementation of Resolution no. 1244 of the United Nations Security Council, and to use its influence in this body to allow Serbia an optimal position in the negotiations on the political status of the southern province. For pragmatic reasons, China insists on a peaceful settlement of the dispute and a compromise that would guarantee equal rights to all peoples living in Kosovo and Metohija. In this way, China refuses to follow the plans of the predominantly Western powers for the territorial redesign of Serbia and seeks to maintain the stability of the existing order by insisting on respect for international law and the general principles of the United Nations Charter (Dimitrijević et al., 2012; Trud, 2007, p. 165).

From the previous analysis, it would be possible to draw appropriate conclusions. Thus, while Serbia considers China to be its most important strategic partner in Asia, its economic relations with China are characterized by mutual asymmetry in all comparable economic parameters (Chamber of Commerce and Industry of Serbia, 2019; Statistical 
Office of the Republic of Serbia, 2019). ${ }^{11}$ However, this does not mean that there is no room for further growth and development of these relationships. This also comes from China's view that Serbia is one of its key partners in the Southeast European region. For China, Serbia is an active functional factor for integration with the European Union, whose huge common market of high purchasing power may be an ideal space for its investment and placement of products and services. Therefore, China supports Serbia's aspirations for full membership of the European Union and encourages its economic transition towards market liberalization. The process of globalization and internationalization of the world economy are contemporary trends that have not bypassed Serbia and China. Both countries seek to follow general trends and integrate into the development of the world economy. Neither can achieve economic growth if left isolated from the world. As China has achieved remarkable achievements in economic development over the past four decades of reform and opening up to the world and has become not only a driver of global economic growth but also a major supporter of world trade and investments, China's economic potential provides Serbia with a chance to achieve its strategic economic interests, above all, in the renewal and development of industrial capacity and the improvement and encouragement of technological progress. Due to the lack of financial resources that would enable the realization of the aforementioned economic interests, Serbia, using its liberalized market and good political relations with China, attracted considerable Chinese investments in the previous decade (for example, in infrastructure, energy and ICT sectors), which should lead to the gradual

\footnotetext{
${ }^{11}$ According to data of the National Bank of Serbia, the total net inflow from China during the period from 2005 to 2013 amounted only to EUR 20 million. From 2010 to 2017, inflows based on investments of Chinese residents in the Republic of Serbia amounted to USD 341.4 million. According to the Serbian Bureau of Statistics and Serbian Chamber of Commerce official data, in 2016, there was an increase in bilateral trade between the two countries. Thus, imports from China amounted to USD 1,522.9 million, while exports from Serbia to China amounted to USD 25.3 million. In 2017, there was further growth. The imports amounted to USD 1,775.1 million, while exports from Serbia was USD 62.2 million. In 2018, there was a successive growth of imports from China so that it was amounting to USD 2,167.5 million, while exports from Serbia to China also recorded a growth of USD 91.7 million. Comparing these indicators, it can be seen that the coverage of exports by imports increased from 1.7 in 2016 to 4.2 in 2018 . This further suggests that the foreign trade exchange between the two countries has gradually increased year by year. According to the latest statistical indicators for 2019, China as the strategic partner of Serbia occupies the fourth place in the foreign trade exchange of Serbia with the world (right behind Germany, Italy and the Russian Federation).
} 
optimization of its economic system (Dimitrijević, 2017). Whether this will actually happen depends on several determinants. First of all, it depends on the Chinese economic strategy, whose main constant is the increasing expansion of exports, the procurement of energy and natural resources for sustainable economic growth and consequently, the global economic positioning and significant logistical and financial support of state-owned banks to foreign companies. ${ }^{12}$ If the aforementioned determinant also takes into account the economic constant that China's economic cooperation with Serbia in terms of size, value and structure is a small part of its economic exchange with the world, then it could be concluded that the achievement of strategic economic interests through cooperation with China's represents a real economic challenge for Serbia (Babić, 2016). However, if the parameters of economic cooperation between Serbia and China are analyzed more closely, it can be concluded that this cooperation is on the rise, not only for the realization of its own economic interests but also for the successful conduct of the foreign policy of both countries. On the one hand, China's foreign policy promotes peace, development and cooperation at the global level, and on the other hand, Serbia's foreign policy promotes Serbia's constructive role in the regional integration of East and West. In this regard, Serbia seeks to increase its influence and importance in economic relations with China and bases its business prospects on the adaptation of the economic structure at the macro and micro levels through the optimization of industrial capacities and various types of investments to achieve a balanced and sustainable economic growth and development. In order to improve its economic system, Serbia is intensively developing cooperation with China. This cooperation is needed for Serbia to continue its integration into the international division of labour through the global value chain, resulting not only from proprietary forms of foreign direct investments (FDI), but also from the socalled non-equity investments (portfolio investments), which enable proportional participation in foreign export (Kozomara, 2014, p. 109). With co-ordinated and joint Serbian-Chinese participation in global value chains, Serbia could realize its development strategy and achieve progressive economic growth and stability. However, this requires that all Chinese investments in Serbia enjoy adequate legal certainty. As these guarantees

\footnotetext{
${ }^{12}$ China is developing this model of economic cooperation with the countries of Central and Eastern Europe (CEEC) through which it seeks to penetrate EU markets. In doing so, China grants soft loans through state-owned banks to major infrastructure projects.
} 
exist (for example, with regard to the equal status of domestic and foreign investors, freedom of investment, national treatment, legal certainty of transferring profits abroad, etc.), it is believed that this creates a good climate necessary for achieving economic priorities to the foreign policy agenda (Law on Foreign Investments, 2014; Politika, 2019).

Based on the analysis of specific foreign policy determinants related to Serbia-China economic cooperation, further conclusions could be drawn regarding the comparative advantages that Serbia has over other developing countries with which China is cooperating. Thus, if it is possible to simplify the analysis, these advantages as foreign policy variables are manifested through Serbia's clear commitment to joining the European Union and the World Trade Organization. Then, the benefits could be seen through relative macroeconomic stability, competitive financial risk, the restructuring and privatization process implemented, rapid development of the capital market, a liberalized tariff and tax legislation, a significant level of fiscal, regulatory and financial incentives, a highly skilled and relatively inexpensive workforce, developed telecommunication and transport infrastructure, etc. The existence of a free trade agreement (FTA) with the European Union, the Central European Free Trade Agreement (CEFTA), the European Free Trade Association (EFTA), the Commonwealth of Independent States (CIS), the Eurasian Economic Union (EAEU) and special agreements with Russia, Belarus, Kazakhstan, Turkey and other countries, the adopted strategy for stimulating and developing foreign investment, a harmonized legal framework for foreign investment with European and international standard, and complete visa liberalization between Serbia and China - may also represent comparative advantages for future Serbia-China economic cooperation, particularly in agriculture, transport and energy, as well as production capacity of the automotive, telecommunications, mechanical, chemical and textile industries, with a view to placing them on third markets. In addition to these comparative advantages, there are also some challenges for the further development of Serbian-Chinese cooperation related to macroeconomic imbalances. This imbalance greatly contributes to the 'accelerated pulse' in relations and directly affects the dynamics and structure of FDI inflows into Serbia, as well as the volume and structure of Serbian exports to China. The prediction of the development of strategic relations between Serbia and China, therefore, requires a rethinking of the ways in which this negative tendency arising from asymmetric bilateral economic cooperation could be stopped. From the analysis of selected macroeconomic parameters, it can be concluded that there is still a chance to transform the volume and structure of Serbian exports to China in line 
with the accelerated inflow of Chinese investment. This transformation would be a clear indication of the strengthening of the economic potential needed for the gradual re-industrialization of the Serbian real sector, and thus for the promotion of 'win-win' economic cooperation. The financial basis for such developments could come in part from the rational accumulation of foreign investment and then from the planned distribution of revenues, which would lead to the consolidation of economic relations and the pursuit of common interests arising from the effective implementation of China's development strategy. (Kozomara, 2014; Dimitrijević and Jokanović, 2016). Considering that China has enormous development potential and that it approaches planning and achieving its strategic development goals in a holistic way, that is, through sectoral integration and market adaptation of different countries, regions, subregions and even continents - it is clear that its development strategy has global significance and that it is a unique determinant of its relations with the world. In this connection, in the next part of the analysis, it is necessary to explain the content and scope of this strategy symbolically named: the 'New Silk Road'.

\section{A unique foreign policy determinant of Serbia-China relations}

The importance of establishing the Comprehensive Strategic Partnership between Serbia and China has had positive effects not only on optimizing Serbia's foreign policy position in international relations but also on implementing the foreign policy goals of China's the 'New Silk Road' development strategy. In this sense, the analysis of contemporary SerboChinese relations requires the realization of the significance of this unique determinant of foreign policy, which conditioned not only these relations but also the entire international relations in the Age of Globalization. Generally speaking, the development strategy of the 'New Silk Road' is an ideological concept of China's foreign policy aimed at preserving world peace and ensuring the common, harmonious and prosperous development of the entire world. Unlike the geopolitical strategies of the great powers, mainly based on the division of spheres of interest, China's 'New Silk Road' strategy is focused on mutual interests and cooperation in order to achieve mutual benefits. Since 1978, when it embarked on economic structural reforms and the implementation of an 'Opening-up Policy', China has sought to strengthen its position in international politics and to contribute actively to globalization through its involvement in international economic integration 
processes (Hongyuan et al., 2012, p. 128) $\cdot{ }^{13}$ Continued social reforms are contributing to the achievement of this 'Chinese dream', to which China is building a new vision of international relations based on the promotion of political, economic and cultural cooperation and social progress between different civilizations. Hence, despite the significant post-Cold War geopolitical changes, strong political influence in international processes and marked opportunism in international relations, China remains a connecting factor in solving major international problems. Faced with new challenges and opportunities, China, as the world's second-largest economy with almost a fifth of the world's population, has pledged internationally to expand good relations with all countries of the world, regardless of their size, ideological and political orientation and the level of economic development. This new, pragmatic approach has determined China's new position in the Global Economic Governance and the New World Order (Dimitrijević, 2018).

China today advocates for greater and balanced cooperation between developed and developing countries, it promotes cooperation in the SouthSouth and South-North directions, and it is also working to fulfil its commitments globally. This positioning emerged from a new foreign policy course that replaces the prevailing concept of 'peaceful rise' with the concept of 'peaceful development' as a precondition for adapting the Chinese model of development to the process of globalization. (Jiabao, 2007; Nye, 2011, p. 11). ${ }^{14}$ In doing so, China has expanded its earlier foreign policy priorities of

${ }^{13}$ The concept of the 'New Silk Road' emerged from strategic reflections on social development in the 1990s. At that time, Deng Xiaoping confirmed his vision of economic reforms based on China's coastal development (especially through special economic zones in coastal provinces, open coastal cities, eastern comprehensive development zones). In this idea, there was no provision for the development of the inland parts of China. Therefore, at the beginning of the 21st century, China made deeper reforms to coordinate the development of all of its regions by adopting the concept of market economy. With the implementation of regional development strategies of the 'Develop the West', 'Revitalize the Northeast' and 'Rise of Central China', and with the establishment of innovative 'state pilot zones for overall reform', China has greatly managed to balance its regional development and improve competitiveness, which enabled it to continue with the implementation of comprehensive economic reforms and the rapid opening of its internal market. This was particularly visible in the period after China joined the World Trade Organization (WTO) in 2001. This period represented a period of major changes since China opened up in all its economic sectors, expanding and deepening its ties with the world, which enabled it to make a bigger impact on foreign direct investment, as well as to strengthen its own export-oriented trade and overseas investment.

${ }^{14}$ Such tactics, in foreign policy practice, was accompanied by a gradual growth of Chinese 'hard power' with an attractive narrative about the growth of 'soft power', which in the 
regional development and stability to be much more receptive goals of peaceful and harmonious development of the world, which in the meantime have become the basis of its new foreign policy doctrine, whose personification is precisely the development strategy of the 'New Silk Road'. Symbolically named after its historical model from ancient times, this development strategy is covered by appropriate foreign policy framework initiatives, namely: the 'Silk Road, Economic Belt' and the '21st Century Maritime Silk Road' (Belt and Road Initiative) (The Decision, 2013; People's Daily, 2013; Dimitrijević and Jokanović, 2016; Ministry of Foreign Affairs of the PRC, 2013).${ }^{15}$ As a novelized ideological concept of China's foreign policy, the development strategy of the 'New Silk Road' is rather abstractly defined without clear geographical, temporal and functional parameters, which does not diminish its global geo-economic significance. Especially since this strategy is based on the ideas of a common and peaceful coexistence, 'win-win' cooperation and comprehensive, balanced and sustainable development (Petrović Piroćanac, 2013). Such a foundation is certainly complementary to China's view that regional integration contributes to economic globalization and that greater connectivity between different regions accelerates the development of global supply, industrial

doctrine of international relations is explained by the premise that China, by 'smart power', seeks to convey the idea of its 'peaceful rise' to eliminate the possibility of a countervailing balance of power.

${ }^{15}$ The New Silk Road development strategy, through its framework foreign policy initiatives, was first proposed by Chinese President Xi Jinping during an official visit to the countries of Central Asia: Turkmenistan, Kazakhstan, Uzbekistan and Kyrgyzstan, and then to Indonesia in October 2014. In his speech in Astana and then on the 13th Shanghai Cooperation Organization (SCO) summit in Bishkek, President Xi emphasized the need of 'jointly building the 'Silk Road Economic Belt' with innovative models of cooperation', between China, Central Asia and Europe. To implement this Initiative, President $\mathrm{Xi}$ suggested that it would be necessary to start work first in specific areas in order to connect them within the entire region. In his later speech in the Indonesian Parliament and on the 10th anniversary of the ASEAN-China strategic partnership, he emphasized the importance of stronger regional integration and maritime cooperation, as well as the promotion of regional interconnectivity for the improvement of the maritime economy, environmental protection, science, technology and security. In this regard, he pledged for the establishment of the Asian Infrastructure Investment Bank with the purpose of financing infrastructure projects along the maritime routes. Also, he stressed that China is fully prepared to cooperate with the ASEAN countries and, in that respect, he supported the effective use of the China-ASEN Maritime Cooperation Fund to develop partnerships in the field of maritime cooperation and joint construction of the '21st Century Maritime Silk Road'. 
and value chains (Dimitrijević, 2018; Yi, 2015). This conclusion comes from specific programmatic documents such as a strategically important act of the National Development and Reform Commission and the Chinese Ministry of Foreign Affairs and Ministry of Commerce published under the title 'Vision and Actions on the Joint Building Silk Road, Economic Belt and 21st Century Maritime Silk Road', from 28 March 2015 (National Development and Reform Commission, Ministry of Foreign Affairs and Ministry of Commerce of the People's Republic of China, 2015). Referring to the previously proposed Belt and Road Initiative, this act essentially defines the development plans of the 'New Silk Road' strategy which includes guidelines for all-round opening and improving economic, financial, cultural, scientific and technological cooperation with the countries of Asia, Africa and Europe to achieve overall progress, regional security (especially in Central Asia), internal political stability and economic prosperity. To implement this act, the National Development and Reform Commission adopted the 'Action Plan for Harmonization of Standards along the Belt and Road (2015-2017)' on 22 October 2015 (National Development and Reform Commission, 2015). Bearing in mind that the Action Plan reaffirms the goals of the 'New Silk Road' development strategy, it also represents a long-term vision of developing China's relations with the world (Escobar, 2015; Compilation and Translation Bureau, Central Committee of Communist Party of China, 2016, p. 210; Dimitrijević, 2018).$^{16}$

The model of development embodied in the aforementioned strategic acts points to the overcoming of an 'Opening-up Policy', and a reform direction that rests solely on structural reforms. Over time, due to the accumulated social problems and uneven internal development, it became obvious that China needs to carry out broader economic reforms by introducing a proactive approach to foreign direct investment to develop its manufacturing and export capacities to further enable foreign markets. With the promotion of the Belt and Road Initiative, China has also begun promoting its FDI, which is part of its global economic strategy and Policies of 'Going Out' and 'Bringing in', which should enable faster flow of goods, services, labour and capital, increase productivity, and a more cost-effective allocation of funds to broadly integrate regional markets and align

\footnotetext{
${ }^{16}$ Implementation of this development strategy under the Action Plan should be in phases, with the gradual accession of states to the Belt and Road Initiative. The first stage encompasses the period until 2021 when the CPC celebrates its anniversary, and the other stage encompasses the period until 2049 when China celebrates its birthday.
} 
countries' economic policies along the 'New Silk Road' ${ }^{17}$ In this regard, the implementation of the 'New Silk Road' strategy should contribute to greater involvement of participating countries in the activities of international and regional organizations and financial institutions in order to integrate them more fully into the development goals of the Belt and Road Initiative. ${ }^{18}$ This positioning does not exclude the possibility of establishing innovative models of cooperation between states or between states and international organizations in order to participate in the Belt and Road Initiative. After all, this is illustrated by the example of the formation of the ' $16+1$ ' mechanism (which in the meantime has grown into the ' $17+1$ ') between the countries of Central, East and Southeast Europe (CESEE) and China which cover various areas of cooperation, starting with infrastructure, finance, trade, transport, agriculture, energy and telecommunications, to scientific, technological, cultural, educational and medical cooperation and people-to-people exchange. This mechanism of cooperation is of great importance for the development of Serbian-Chinese relations because through it Serbia has become a major 'hub' for Chinese FDI in Serbian transport, infrastructure, energy, metallurgy, ICT and other industrial sectors. In this way, the ' $17+1$ ' mechanism gave impetus to the establishment of Comprehensive Strategic Cooperation, which encouraged new Chinese investments in Serbia, which according to official figures amount to over USD 10 billion (Zakić and Radišić, 2019). ${ }^{19}$ In this regard,

${ }^{17}$ In essence, the 'New Silk Road' strategy seeks to overcome the weaknesses of the current global economic order and accelerate the revitalization of a large part of the world that covers a wider area with more than 4.6 billion people with a production capacity of 21 trillion US dollars (almost one-third of world GDP).

${ }^{18} \mathrm{n}$ this regard, it does not exclude cooperation with existing organizations such as the Shanghai Cooperation Organization (SOS), the Eurasian Economic Union (EAEU), ASEAN plus China, Asia-Pacific Economic Cooperation (APEC), Asia-Europe Meeting (ASEM), Central Asia Regional Economic Cooperation (CAREC), the Asia-Pacific Dialogue (APD), the Asia Cooperation Dialogue (ACD), the Conference on Interaction and Conference Building Measures in Asia (CICA), the China-Arab States Cooperation Forum, the Strategic Dialogue between China and the Gulf Cooperation Committee, the Economic Community of Brazil, Russia, India, China and the South African Union (BRICS) and financial institutions such as the Asian Infrastructure Investment Bank (AIIB), the (BRICS) New Development Bank (NDB), the China, Central \& Eastern Europe Investment Co-operation Fund (CEEFund) and the Silk Road Fund (SRF), which represent a counterpart to the transatlantic system monetary economies carried out by the World Bank (WB), the International Monetary Fund (IMF) and the Asian Development Bank (ADB).

${ }^{19}$ Of particular importance in this regard are Chinese investments in 'Smederevo' steelworks, in the 'Mining Smelter Basin Bor', in the construction of the Zemun-Borča bridge, in the 
Chinese investment has become a key impetus for economic growth in Serbia. On the other hand, the rapid attractiveness of Chinese investments has also brought with it greater indebtedness of Serbia and its responsibility in the international financial market. To avoid possible macroeconomic imbalances, Serbia generally would have to pay more attention to the structure of total FDIs and their sectoral distribution in order to achieve stable and sustainable economic growth through this form of capital. Finally, if Serbia wants to increase its influence and importance in international relations based on economic cooperation with China, its business with China must be built not only on past successes and achievements, but also on potentials that will be grounded on improving its real economic capacity through different types of investments.

\section{CONCLUSION}

The changing world geopolitical circumstances justify the new strategic positioning of Serbia and China in international relations. In this regard, pursuing the current foreign policy priorities of the two countries involves examining the international environment and monitoring their vital national interests. Assuming that Serbo-Chinese relations should contribute to the faster political consolidation, economic development and social progress, the study analyzed the general, specific and unique determinants of SerboChinese relations. Namely, using appropriate scientific methods, the author of the study wanted to demonstrate the validity of the initial hypothesis that the current strategic cooperation between Serbia and China depends not only on spatial, temporal and institutional factors, which are obviously asymmetrical, but also on global economic factors that may contribute to deepening this cooperation. In this regard, the author has come to some conclusions that may be relevant for formulating the principles and goals of future cooperation. Thus, Serbia, as the successor state of socialist Yugoslavia, should maintain the continuity of traditionally good relations with China, but also working to constantly improve them in line with the opportunities offered by the Comprehensive Strategic Partnership. As a kind

construction of the Belgrade-Budapest fast railway on the part of the international Corridor 10 , in the construction of parts of the international corridor 11, in the construction of a new Block 3 of the thermal power plant Kostolac ' $\mathrm{B}$ ', in the construction of the Block 3 Thermal Power Plant 'Nikola Tesla B' in Obrenovac, in the modernization of the integrated system of telecommunications and the construction of the Innovation Center for Digital Transformation, etc. 
of political instrument, the Comprehensive Strategic Partnership should facilitate the cooperation and development of friendly relations between the two countries at different levels and different social fields. This is all the more so since both countries are in the process of regrouping into a new multipolar system of international relations and reconciling their own national interests, which are more precisely defined in their foreign policy doctrines. Finally, the study shows that Serbia and China do not have to change their good practices and foreign policy priorities, among which the development of 'steel cooperation' is not only a common interest but also a significant objective of their mutually beneficial foreign policy. This policy is framed by the unique development strategy of the 'New Silk Road' and the Belt and Road initiative, whose directions in interstate relations define the ' $17+1$ ' cooperation mechanism as a new form of foreign policy that deepens earlier ideological concepts of global economic development and reform of world society in a 'community of common interests, destinies and responsibilities' or in other words, into a 'community of the common future of mankind' (Permanent Mission of the PRC to the United Nations Office at Geneva, 2018).

\section{REFERENCES}

Allot, P. (1998). The True Function of Law in International Community, Indiana Journal of Global Legal Studies, 5(2), pp. 391-414.

Almond, R.G. (2018, January 18). Deciphering U.S. Foreign Policy in the Trump Era. The Diplomat, retrieved from https://thediplomat.com/ 2018/01/deciphering-u-s-foreign-policy-in-the-trump-era/. Accessed 18 January 2020.

Babić, B. (2016). New Silk Road - China's New deal, in: D. Dimitrijević (Ed.), Danube and the New Silk Road (pp. 45-68). Belgrade, Institute of International Politics and Economics.

Baijlie, A. (2014, May 5). Peaceful coexistence a cornerstone of foreign policy. China Daily, retrieved from http://www.chinadaily.com.cn/kindle/ 2014-05/28/content_17547189.htm. Accessed 7 September 2019.

Bhutia, T.C. (2015, November 24). Tibet, Taiwan and China - A Complex Nexus. The Diplomat, retrieved from http:/ / thediplomat.com/2015/11/ tibet-taiwan-and-china-a-complex-nexus/. Accessed 24 December 2019.

Buzan, B. (2004). The United States and the Great Powers. Cambridge, Polity Press. 
Chamber of Commerce and Industry of Serbia. (2019, January 1). Foreign trade of the Republic of Serbia and the People's Republic of China, retrieved from https://api.pks.rs/storage/assets/KINA.pdf. Accessed 19 October 2019.

Compilation and Translation Bureau, Central Committee of Communist Party of China. (2016). The 13th Five-Year Plan for Economic and Social Development of the Peoples Republic of China (2016-2020), retrieved from https://en.ndrc.gov.cn/newsrelease_8232/201612/P02019110148 1868235378.pdf. Accessed 22 October 2019.

Constitution of the Republic of Serbia, Official Gazette, no. 98 (2006).

Darlington, R. (2018, February 27). A Short Guide to the Chinese Political System, retrieved from http://www.rogerdarlington.me.uk/Chinese politicalsystem. Accessed 27 September 2019.

Dimitrijević, D. (2007). United Nations Interim Administration in Kosovo and Metohija and protection of property rights, Teme, 31(3), pp. 473-510.

Dimitrijević, D., Vučić, M. \& Lađevac, I. (2012). An Analysis of Actions Taken under the UN System to Address Kosovo and Metohija Issues, Međunarodni problemi, 64(4), pp. 442-478.

Dimitrijević, D. \& Jokanović, N. (2016). China's ‘New Silk Road' Development Strategy, Review of International Affairs, LXVII(1161), pp. 21-44.

Dimitrijević D. \& Vučić, M. (2016). Globalisation and the New World Order, in: B. Đorđević, T. Tsukimura \& I. Lađevac (Eds.), Globalised World: Advantage or Disadvantage (pp. 9-28), Belgrade, Institute of International Politics and Economics.

Dimitrijević, D. (2017). Chinese Investment in Serbia-joint Pledge for the Future of the New Silk Road, Baltic Journal of European Studies, 7(1/22), pp. 64-83.

Dimitrijević, D. (2018). China's New Silk Road: The Opportunity for Peaceful World Development, in: S. Chizhikov, A. Dmitirev \& B. Kabylinski (Eds.), Development of Trade in Modern World: Innovation and Challenges. Saint-Petersburg, Russian Academy of National Economy and Public Administration, North West Institute of Management, Publishing House NWIM.

Escobar, P. (2015, February 24). The 21st century belongs to China: Why the new Silk Road threatens to end America's economic dominance, retrieved from http://www.salon.com/2015/02/24/the_21st_century _belongs_to_china_why_the_new_silk_road_threatens_to_end_america s_economic_dominance_partner/. Accessed 24 February 2017. 
Gleni, M. (2001). Balkan (1804-1999): Nationalism, War and the Great Powers. Belgrade, Samizdat B92.

Global Fire Power. (2019). 2019 China Military Strength: Current military capabilities and available firepower for the nation of China", retrieved from https://www.globalfirepower.com/country-military-strengthdetail.asp?country_id=china. Accessed 22 October 2019.

Global Fire Power (2019). 2019 Serbia Military Strength: Current military capabilities and available firepower for the nation of Serbia, retrieved from https://www.globalfirepower.com/country-military-strengthdetail.asp?country_id=Serbia. Accessed 12 January 2020.

Haas, E. B. (1964). Beyond the Nation-State, Functionalism and International Organization, Stanford, University Press.

Heath, R., Gunness, K. \& Cooper, C.A. (2016). The PLA and China's Rejuvenation: National Security and Military Strategies, Deterrence, Concepts, and Cobat Capabilitie, Santa Monica, RAND Corporation.

Hongjun, Y. (2013). Sincere Dialogue for Conductive Cooperation, in: The Changing World and China in Development - The Contemporary World Multilateral Dialogue. Beijing, China Centre for Contemporary World Studies and China Foundation for Peace and Development.

Hongyuan, L., Yun, G. \& Qifa, S. (2012). China's Road. Beijing, Huangshan Publishing House.

International Monetary Fund (2019, October). World Economic Outlook Database, retreived from https://www.imf.org/external/pubs/ft/ weo $/ 2019 / 02 /$ weodata/weorept.aspx?pr. $x=40 \&$ pr.y $=13 \& s y=2017 \&$ ey $=2021 \& \mathrm{scsm}=1 \& \mathrm{ssd}=1 \&$ sort $=$ country $\& d s=. \& b r=1 \& \mathrm{c}=942 \& \mathrm{~s}=\mathrm{NGDPD}$ $\%$ 2CPPPGDP $\% 2$ CNGDPDPC $\% 2$ CPPPPC $\% 2$ CPCPIPCH\&grp=0\&a $=$. Accessed 22 October 2019.

International Monetary Fund. (2019), Report for Selected Countries and Subjects: China. World Economic Outlook, retrieved from https:// www.imf.org/en/Countries/CHN. Accessed 22 October 2019.

Isac Fund (2013). Od četiri stuba spoljne politike do evropskih integracija: postoji li volja za strateško usmerenje spoljne politike Srbije? [From the four pillars of foreign policy to European integration - is there a will to strategically focus Serbia's foreign policy?], retrieved from https:// www.isac-fund.org/download/Od_cetiri_stuba_spoljne_politike_ do_evropskih_integracija.pdf. Accessed 1 January 2019.

Jiabao, W. (2007, March 12). Our Historical Tasks at the Primary Stage of Socialism and Several Issues Concerning China's foreign Policy. Bejing 
Review, retrieved from http://www.bjreview.com/lianghui/txt/200703/12/content_58768.htm. Accessed 30 December 2019.

Keith, R. C. (2009). China from the Inside Out: Fitting the People's Republic into the World, London, Pluto Press.

Koskenniemi, M. (1989). From Apology to Utopia, the Structure of International Legal Argument. Helsinki, Lakimiesliiton Kustannus.

Kozomara, J. (2014). Serbia in international production through global value chain, in: P. Petrović (Ed.), Possibilities and perspectives for foreign direct investments in the Republic of Serbia (pp. 109-110). Belgrade, Institute of International Politics and Economic.

Law on Foreign Investments, Official Gazette, no. 107 (2014).

Law on the budget of the Republic of Serbia for 2019, Official Gazette no. 95 (2018), 72 (2019).

Ministry of Foreign Affairs of the PRC (2009, August 20). Joint Statement by the Republic of Serbia and the People's Republic of China on the Establishment of a Strategic Partnership retrieved from https:/ / www. fmprc.gov.cn/mfa_eng/wjdt_665385/2649_665393/t581207.shtml. Accessed 11 January 2020.

Ministry of Foreign Affairs of the PRC (2010, October 10). Premier Li Keqiang attends the 16th ASEAN-China Summit, Stressing to Push for Wide-ranging, In-depth, High-level, All-dimensional Cooperation between China and ASEAN and Continue to Write New Chapter of Bilateral Relations, retrieved from http:/ / www.fmprc.gov.cn/mfa eng/topics_665678/lkqzlcxdyldrxlhy_665684/t1088098.shtml. Accessed 10 October 2013.

Ministry of Foreign Affairs of the PRC (2013, August 26). Joint statement by the Republic of Serbia and the People's Republic of China on deepening the strategic partnership, retrieved from https://www.fmprc.gov.cn/ mfa_eng/wjb_663304/zzjg_663340/xos_664404/gjlb_664408/3260_664 742/3262_664746/t1069919.shtml. Accessed 11 January 2020.

Ministry of Foreign Affairs of the PRC (2015, July). Report on China's Implementation of the Millennium Development Goals (2000-2015), retrieved from https://www.fmprc.gov.cn/mfa_eng/zxxx_662805/ W020150730508595306242.pdf. Accessed 11 January 2020.

Ministry of Foreign Affairs of the PRC (2016, June 18). Joint Declaration by the Republic of Serbia and the People's Republic of China on establishing a comprehensive strategic partnership, Belgrade, retrieved from www.fmprc.gov.cn, Accessed 11 October 2019. 
Ministry of Foreign Affairs of the PRC. (2018). China's Initiation of the Five Principles of Peaceful Co-Existence retrieved from http:/ / www.fmprc. gov.cn/mfa_eng/ziliao_665539/3602_665543/3604_665547/t18053.sht ml. Accessed 27 September 2018.

Mitrović, D. (2008). Models for deepening cooperation with the People's Republic of China and the countries of Central and East Asia, in: E. StojicKaranović \& S. Janković (Eds.), Elements of the Foreign Policy Strategy of Serbia. Belgrade, Institute of International Politics and Economics.

National Bureau of Statistics of China (2011, April 28). Communiqué of the National Bureau of Statistics of People's Republic of China on Major Figures of the 2010 Population Census (No.1), retrieved from http://www.stats.gov.cn/english/NewsEvents/201104/t20110428_264 49.html. Accessed 12 Deecember 2019.

National Development and Reform Commission. (2015, October 22). Action Plan for Harmonisation of Standards along the Belt and Road (20152017), retrieved from http:/ / china-trade-research.hktdc.com/businessews/article/One-Belt-One-Road/Action-Plan-for-Harmonisation-of-Sta ndards-Along-the-Belt-and-Road-2015-2017/obor/en/1/1X000000 /1X0A443L.htm. Accessed 8 March 2016.

National Development and Reform Commission. (2015, March 28). Vision and Actions on Jointly Building Silk Road Economic Belt and 21stCentury Maritime Silk Road retrieved from http://en.ndrc.gov.cn/ newsrelease/201503/t20150330_669367.html. Accessed 8 March 2016.

Obradović, Ž. (2016). Strateško partnerstvo male Srbije i velike Kine unutrašnji i međunarodni aspekti saradnje. [Strategic partnership of small Serbia and big China - domestic and international aspects of cooperation], Srpska politička misao [Serbian Political Thought], 53(3), pp. 121-137.

Pečujlić, M. (2005). Globalizacija: dva lika sveta [Globalization: the two faces of the World]. Belgrade, Gutembergova galaksija.

People's Daily (2013, September 8). Promote Friendship between Our People and Jointly Build Silk Road Economic Belt, retrieved from http://en. people.cn/review/20130908.html. Accessed 4 December 2016.

Perlo-Freemen, S. (2014, March 31). Deciphering China's latest defence budget figures, retrieved from https://www.sipri.org/node/377. Accessed 12 January 2020.

Permanent Mission of the PRC to the United Nations Office at Geneva (2017, December 1). Working Together to Build a Better World, Keynote 
Address by H.E. Xi Jinping General Secretary of the Central Committee of the Communist Party of China and President of the People's at the CPC in Dialogue with World Political Parties High-Level Meeting Republic of China Beijing, retrieved from http://www.china-un.ch/ eng/zywjyjh/t1530652.htm Accessed 31 January 2018.

Petrović Piroćanac, Z. (2014). The World and a Chinese Non-alignment Strategy of Governance and Development-Brief Survey, in: Global Trends and China in the Coming Decade - Contemporary World Multilateral Dialogue 2013. Beijing, China Centre for Contemporary World Studies, China Foundation for Peace and Development, China Energy Fund Committee.

Politika (2019, January 5). Chinese miracle in Serbia, investments of close to $\$ 10$ billion, retrieved from http://www.politika.rs/sr/clanak/419657/ Kinesko-cudo-u-Srbiji-investicije-od-blizu-10-milijardi-dolara. Accessed 10 January 2019.

Van der Putten, F.P. \& Shulong, C. (2011). China, Europe and International Security: Interests, Roles, and Prospects, London/New York, Routledge.

Qingmin, Z. (2014). Contemporary China's Diplomacy. Beijing, China Intercontinental Press.

Resolution of the National Assembly of Serbia on the Protection of the Sovereignty, Territorial Integrity and Constitutional Order of the Republic of Serbia, Official Gazette, no. 125 (2007).

Riphagen, W. (1975). Some Reflection on Functional Sovereignty. Netherlands Yearbook of International Law, 6, pp. 121-165.

Šehić, D., Šehić D. \& Bertić, I. (2007). Atlas of Asia. Belgrade, Monde Neuf.

Statistical Office of the Republic of Serbia. (2019). Serbian Statistical Office Data, retrieved from http:// data.stat.gov.rs/?caller=SDDB\&language Code=en-US. Accessed 19 October 2019.

Swaine, M.D. (2017, October 16). The 19th Party Congress and Chinese Foreign Policy, retrieved from http://carnegieendowment.org/2017/ 10/16/19th-party-congress-and-chinese-foreign-policy-pub-73432. Accessed 16 January 2019.

Tanjug. (2016, June 18). China and Serbia - Strategic Partnership and 21 more agreements, retrieved from http://www.tanjug.rs/full-view.aspx? item $=270618 \& i z b=252463 \& v=252463$. Accessed 29 September 2016.

The State Council of the PRC. (2014, August 23). Constitution of the People's Republic of China retrieved from http:/ /english.gov.cn/archive/laws regulations/2014/08/23/content_281474982987458.htm. Accessed 17 October 2018. 
The Decision on Major Issues Concerning Comprehensively Deepening Reforms in brief (2013, November 16), retrieved from http:// www.china.org.cn/china/third_plenary_session/2013-11/16/content _30620736.htm. Accessed 10 January 2020.

Trud, A. (2007). Geopolitika Srbije [Geopolitics of Serbia]. Beograd, Službeni glasnik.

United Nations Department of Economic and Social Affairs (2019). World Population Prospects: the 2019 Revision, retrieved from https:// population.un.org/wpp/Publications/Files/WPP2019_DataBooklet.pd f. Accessed 10 January 2020.

United Nations (1958). Agreement (with exchange of notes) on trade and intercourse between Tibet Region of China and India, retrieved from https://treaties.un.org/doc/publication/unts/volume\%20299/v299.p df. Accessed 10 January 2020.

United Nations (2000, September 18). United Nations Millennium Declaration, United Nations General Assembly, Res/ 55/2, retrieved from https:// www.un.org/en/development/desa/population/migration/general assembly/docs/globalcompact/A_RES_55_2.pdf. Accessed 10 January 2020.

United Nations (2015, September 25). Transforming our World: the 2030 Agenda for Sustainable Development, Res/A/70/L.1, retrieved from https://sustainabledevelopment.un.org/post2015/transformingourwo rld. Accessed 10 January 2020.

White House (2017, December). National Security Strategy of the USA, Washington D.C.

Yang, J. (2010). China Security Challenges: Priorities and Policy Implications, in: Asia Pacific Countries' Security Outlook and Its Implications for the Defense Sector (pp. 141-159). Tokyo, National Institute for Defense Studies (NIDS).

Yi, H. (2015, March 20). China's ‘One Belt/One Road' Policy Is Open to All Nations, Executive Intelligence Review, retrieved from https://inss. ndu.edu/Portals/68/Documents/stratperspective/china/ChinaPerspe ctives-12.pdf. Accessed 10 January 2020.

Zakić, K. \& Radišić, B. (2019). China's Belt and Road Investment Projects in the Balkan Countries: Six Years After, The Review of International Affairs, 70(1175), pp. 48-68. 